\title{
The antibacterial peptide from Bombyx mori cecropinXJ induced growth arrest and apoptosis in human hepatocellular carcinoma cells
}

\author{
LIJIE XIA $^{1}$, YANLING WU ${ }^{1}$, JI MA ${ }^{1}$, JIANHUA YANG ${ }^{2}$ and FUCHUN ZHANG ${ }^{1}$ \\ ${ }^{1}$ Xinjiang Key Laboratory of Biological Resources and Genetic Engineering, College of Life Science and Technology, \\ Xinjiang University, Urumqi, Xinjiang 830046, P.R. China; ${ }^{2}$ Department of Pediatrics, \\ Texas Children's Cancer Center, Dan L. Duncan Cancer Center, Baylor College of Medicine, Texas, TX 77030, USA
}

Received January 14, 2015; Accepted April 12, 2016

DOI: $10.3892 / \mathrm{ol} .2016 .4601$

\begin{abstract}
CecropinXJ is a cationic antimicrobial peptide originally isolated from the larvae of Bombyx mori. The anticancer effect of cecropinXJ has been reported in various tumor cells, including leukemia, gastric and esophageal cancer cells. However, the activity of cecropinXJ on hepatocellular carcinoma (HCC) and its underlying mechanism have not been investigated to date. Therefore, the present study investigated the efficacy and associated mechanism of cecropinXJ in Huh-7 cells. Flow cytometric analysis was performed to determine the presence of cell cycle arrested and apoptotic cells. CecropinXJ significantly inhibited the growth of Huh-7 cells in a dose- and time-dependent manner. CecropinXJ treatment for $24 \mathrm{~h}$ induced $\mathrm{S}$ cell cycle arrest and apoptosis, in addition to loss of the mitochondrial membrane potential, in hepatoma cells. CecropinXJ induced HCC cell apoptosis by activating caspase-3 and poly(ADP-ribose) polymerase. Furthermore, cecropinXJ downregulated the expression of B-cell lymphoma 2 (Bcl-2), while upregulated the expression of $\mathrm{Bcl}-2$-associated death promoter and Bcl-2-associated $X$ protein. In conclusion, the results of the present study suggest that cecropinXJ may be an active anti-HCC agent and provide novel insights into the mechanism of cecropinXJ.
\end{abstract}

\section{Introduction}

Hepatocellular carcinoma (HCC) is a prevalent type of cancer worldwide, with $>600,000$ individuals succumbing to the

Correspondence to: Professor Fuchun Zhang, Xinjiang Key Laboratory of Biological Resources and Genetic Engineering, College of Life Science and Technology, Xinjiang University, 666 Shengli Road, Urumqi, Xinjiang 830046, P.R. China

E-mail: zfcxju@xju.edu.cn

Key words: antimicrobial peptide, hepatocellular carcinoma, apoptosis, cell cycle disease each year (1). In China, HCC exhibits an incidence of 30.3 cases per 100,000 individuals (2). Similar to other solid tumors, the main curative therapy for HCC is surgery, which generally is only successful if the cancer is diagnosed at an early stage (3). The conventional chemotherapies and radiotherapies used to treat advanced or late-stage HCC tumors, despite being reasonably effective, have also demonstrated various side effects, including hepatotoxicity (4) and hematotoxicity (5), and only a small percentage of patients may have the chance to undergo surgery for radical therapy, which complicates the safe administration of systemic therapy.

Numerous types of cancer cells and microorganisms have relatively more anionic phospholipids in the outer layer of their external membrane compared with normal eukaryotic cells. Several studies have demonstrated that certain antimicrobial peptides (AMPs) are more cytotoxic against transformed cells than against non-transformed cells $(6,7)$. In addition, certain AMPs, when administered locally to solid tumors, exhibit anticancer activity (8). The cecropins, which were first isolated by Boman et al (9) from Hyalophora cecropia pupae $(9,10)$, are a family of AMPs. To date, $>20$ types of cecropins have been identified, some of which have been reported to possess antitumor activities against various cancer cells, including bladder cancer (11), HCC (12), gastric carcinoma (13), fibrosarcoma (14) and leukemia cells (15). The mechanisms of action of cecropins against prokaryotic cells have been widely investigated (16). Cecropins exert their cytolytic activity by folding into an amphipathic helix, following selective binding and insertion into the target membrane, leading to the breakdown of the membrane structure, thus causing leakage of the cell contents and resulting in cell death (17). In eukaryotic cells, cecropins target non-polar lipid cell membranes, whereby they form transmembrane channels, which leads to irreversible cytolysis and eventually cell death (18). In addition, certain cecropins translocate spontaneously across eukaryotic membranes into the cytoplasm, whereby they depolarize inner mitochondrial membranes, thus causing disruption of the mitochondrial membrane potential, release of mitochondrial cytochrome $c$ (cyt $c$ ) and induction of apoptosis (19).

CecropinXJ, a polypeptide composed of 33 amino acid residues, is a cationic AMP isolated from the larvae of 
Bombyx mori (20). CecropinXJ exhibits $98 \%$ homology with cecropin B (20). In the present study, the cecropinXJ gene was cloned into the pYES2/CT/ $\alpha$-Factor expression vector, and expressed in Saccharomyces cerevisiae (21).

CecropinXJ was previously demonstrated to exhibit various antibacterial activities (22). In addition, previous studies have reported that cecropin $\mathrm{XJ}$ is able to inhibit the proliferation and induce the apoptosis of tumor cells (23), although its antitumor mechanism remains unclear. In the present study, the cytotoxicity and mechanism of cecropinXJ against the human HCC cell line Huh-7 was investigated. The results revealed that cecropinXJ suppressed the proliferation and induced the apoptosis of Huh-7 cells in vitro through mitochondrial apoptosis pathways, suggesting that cecropinXJ is a potential anticancer drug.

\section{Materials and methods}

Preparation of the AMP cecropinXJ and reagents. CecropinXJ of $B$. mori was prepared using the $S$. cerevisiae eukaryotic pYES2/CT/ $\alpha$-Factor expression system (Invitrogen; Thermo Fisher Scientific, Inc., Waltham, MA, USA), and purified with Ni-nitrilotriacetic acid agarose, as previously reported (21). The concentration of purified recombinant cecropinXJ protein was determined with a Bradford protein assay kit (BioTek China, Beijing, China). Prior to use, the peptide was dissolved in Dulbecco's modified Eagle's medium (DMEM) (HyClone; GE Healthcare Life Sciences, Logan, UT, USA) at a concentration of $50 \mathrm{mmol} / \mathrm{l}$, and sterilized by filtration through a $0.22-\mu \mathrm{m}$ filter.

Fetal bovine serum (FBS) was obtained from Gibco (Thermo Fisher Scientific, Inc., Waltham, MA, USA), while dimethyl sulfoxide (DMSO) was purchased from Beijing Solarbio Science \& Technology Co., Ltd. (Beijing, China), 3-(4,5-dimethylthiazol-2-yl)-2,5-diphenyltetrazolium bromide (MTT) was acquired from, 3,3'-dihexyloxacarbocyanine iodide $\left[\mathrm{DiOC}_{6}(3)\right]$ was obtained from Sigma-Aldrich (St. Louis, MO, USA), cell cycle staining solution was purchased from Multi Sciences (Lianke) Biotech Co., Ltd. (Hangzhou, China) and Annexin V-fluorescein isothiocyanate (FITC)/propidium iodide (PI) staining apoptosis detection kit was acquired from BestBio (Shanghai, China). Monoclonal rabbit anti-caspase 3 (\#9664), monoclonal rabbit anti-poly(ADP-ribose) polymerase (PARP; \#9532), monoclonal rabbit anti-cytochrome c (\#11940), monoclonal mouse anti-B-cell lymphoma 2 (Bcl-2; \#15071), monoclonal mouse anti-Bcl-2-associated death promoter (Bad; \#9296), monoclonal rabbit anti-Bcl-2-associated X protein (Bax; \#14796), monoclonal rabbit anti-glyceraldehyde 3-phosphate dehydrogenase (GAPDH; \#2118) (dilution, 1:1,000) were all obtained from Cell Signaling Technology, Inc., Danvers, MA, USA. CytoBuster ${ }^{\mathrm{TM}}$ protein extraction reagent was purchased from Novagen (Merck Millipore, Darmstadt, Germany), bicinchoninic acid (BCA) assay kit was acquired from Beyotime Institute of Biotechnology (Haimen, China) and enhanced chemiluminescence detection kit was obtained from CWbio. Co. Ltd. (Beijing, China).

Cell culture. The human HCC cell line Huh-7 was purchased from the Chinese Academy of Medical Sciences (Beijing, China). Cells were cultured in DMEM supplemented with
$10 \% \mathrm{FBS}, 100 \mu \mathrm{g} / \mathrm{ml}$ streptomycin and $100 \mathrm{U} / \mathrm{ml}$ penicillin in a humidified atmosphere of $5 \% \mathrm{CO}_{2}$ in air at $37^{\circ} \mathrm{C}$.

Cell viability assay. To evaluate the effects of cecropinXJ on the proliferation of Huh-7 cells, cell viability was measured by MTT assay. Huh-7 cells in the logarithmic phase of growth were collected, seeded in 96-well plates at a density of $2 \times 10^{3}$ cells/well and cultured overnight. Following $24 \mathrm{~h}$, Huh-7 cells were treated with or without cecropinXJ at various concentrations $(1,5,10$ and $50 \mu \mathrm{mol} / \mathrm{l})$ for $0,24,48$, 72, 96 and 120 h. Bovine serum albumin (10 $\mu \mathrm{mol} / \mathrm{l}$; Beijing Solarbio Science \& Technology Co., Ltd.) served as a negative control, while $10 \mu \mathrm{mol} / 1$ cisplatin (Beijing Solarbio Science $\&$ Technology Co., Ltd.) served as a positive control. Upon incubation, the culture medium was removed, and $100 \mu \mathrm{l}$ MTT solution $(5 \mathrm{mg} / \mathrm{ml})$ was added to each well, followed by incubation at $37^{\circ} \mathrm{C}$ for $4 \mathrm{~h}$. Then, $150 \mu \mathrm{l}$ DMSO was added to each well, and the plates were incubated at $37^{\circ} \mathrm{C}$ for additional $10 \mathrm{~min}$. Absorbance was measured at 540 and $655 \mathrm{~nm}$ using a 96-well microplate reader (Bio-Rad Laboratories, Inc., Hercules, CA, USA), and the ratio of optical density $(\mathrm{OD})_{540 / 655}$ was determined. Cell viability (\%) was calculated as $\left(\mathrm{OD}_{\text {treatment }}-\mathrm{OD}_{\text {blank }}\right) /\left(\mathrm{OD}_{\text {control }}-\mathrm{OD}_{\text {blank }}\right) \times 100$.

Cell cycle analysis of cecropinXJ effects on Huh-7 cells by flow cytometry. Huh-7 cells at $5 \times 10^{5}$ cells $/ \mathrm{ml}$ were inoculated into $100-\mathrm{mm}$ dishes and incubated at $37^{\circ} \mathrm{C}$ for $24 \mathrm{~h}$. Once the medium had been removed, cells were treated for $24 \mathrm{~h}$ with cecropinXJ at a final concentration of 5, 10 and $50 \mu \mathrm{mol} / 1$. Untreated cells served as the control. Upon culture, both floating and adherent cells were collected, washed with cold phosphate-buffered saline (PBS; Beijing Solarbio Science \& Technology Co., Ltd.) ( $\mathrm{pH} 7.4$ ) and fixed with $75 \%$ ethanol overnight at $-20^{\circ} \mathrm{C}$. Cells were then treated with DNA staining solution at $37^{\circ} \mathrm{C}$ in the darkness for $30 \mathrm{~min}$. Samples were analyzed by fluorescence-activated cell sorting (FACS) with a flow cytometer (BD Biosciences, Franklin Lakes, NJ, USA). Cell cycle analysis was performed using the ModFit LT $^{\mathrm{TM}} 3.0$ DNA analysis software (Verity Software House, Inc., Topsham, ME, USA).

Apoptosis rate determined by flow cytometry. Huh-7 cells at $5 \times 10^{5}$ cells $/ \mathrm{ml}$ were inoculated into $60-\mathrm{mm}$ dishes and incubated at $37^{\circ} \mathrm{C}$ for $24 \mathrm{~h}$. Upon removal of the medium, $2 \mathrm{ml}$ complete DMEM with cecropinXJ at a final concentration of 5, 10 and $50 \mu \mathrm{mol} / 1$ was added to each dish, and cells were incubated for 12, 24 and $48 \mathrm{~h}$. Untreated cells served as the control. Subsequently, cells were collected following digestion with $0.25 \%$ trypsin, washed with PBS (two times) and suspended in $400 \mu \mathrm{l}$ binding buffer. Cell suspensions were stained with $5 \mu \mathrm{l}$ Annexin V-FITC and $10 \mu \mathrm{l}$ PI, according to the manufacturer's protocol, prior to be subjected to flow cytometry analysis in a (BD Biosciences). The results are presented as the percentage of Annexin V+ cells (mean \pm standard error).

Measurement of the mitochondrial membrane potential $\left(\Delta \psi_{m}\right)$. Changes in the $\Delta \psi_{\mathrm{m}}$ during apoptosis were measured using $\operatorname{DiOC}_{6}(3)$, which is a lipophilic cationic dye. Huh-7 cells $\left(5 \times 10^{5}\right.$ cells $\left./ \mathrm{ml}\right)$ were cultured in $100-\mathrm{mm}$ dishes in the absence or presence of cecropinXJ for $24 \mathrm{~h}$ at a concentration 
of $0,5,10$ and $50 \mu \mathrm{mol} / 1$. Subsequently, cells were incubated with $40 \mathrm{nmol} / 1 \mathrm{DiOC}_{6}(3)$ for $15 \mathrm{~min}$ at $37^{\circ} \mathrm{C}$. Cells were then washed twice in PBS and fluorescence was measured using a fluorescence spectrophotometer with an excitation wavelength of $482 \mathrm{~nm}$ and an emission wavelength of $504 \mathrm{~nm}$.

Western blotting. Huh-7 cells were incubated with $0,1,5$, 10 and $50 \mu \mathrm{mol} / \mathrm{l}$ cecropinXJ for $24 \mathrm{~h}$, followed by two washes with ice-cold PBS. The adherent and floating cells were next harvested and lysed in $100 \mu \mathrm{l} \mathrm{CytoBuster}{ }^{\mathrm{TM}}$ protein extraction reagent on ice for $15 \mathrm{~min}$. Following centrifugation at $12,000 \mathrm{rpm} 4^{\circ} \mathrm{C}$ for $10 \mathrm{~min}$, the protein concentration of the supernatant was determined by BCA assay. The protein lysates ( $40 \mu \mathrm{g} /$ lane) were separated by $12 \%$ sodium dodecyl sulfate-polyacrylamide gel electrophoresis, and transferred onto nitrocellulose membranes. Upon being washed with Tris-buffered saline and Tween 20 (TBS-T) buffer $(20 \mathrm{mM}$ Tris- $\mathrm{HCl}, 150 \mathrm{mM} \mathrm{NaCl}$ and $0.05 \%$ Tween 20 ), the membranes were blocked with 5\% skimmed milk at room temperature for $1 \mathrm{~h}$, and then incubated with the aforementioned primary antibodies $(1: 2,000)$ overnight at $4^{\circ} \mathrm{C}$. Subsequently, membranes were washed with TBS-T and incubated with the corresponding HRP-conjugated secondary antibodies for $2 \mathrm{~h}$ at room temperature. Upon washing with TBS-T, the membranes were exposed using an ECL detection kit (CWbio. Co. Ltd.). Proteins were visualized using the Odyssey ${ }^{\circledR}$ CLx Imaging system (Li-Cor, Lincoln, NE, USA).

Statistical analysis. All results were confirmed in $\geq 3$ independent experiments. Data are expressed as the mean \pm standard deviation. Differences between two sample means were assessed by Student's $t$ test. $\mathrm{P}<0.05$ was considered to indicate a statistically significant difference.

\section{Results}

CecropinXJ suppressed Huh-7 cell proliferation and decreased cell viability. The results of MTT assay revealed that B. mori cecropinXJ inhibited the proliferation of Huh-7 cells in a dose- and time-dependent manner. CecropinXJ treatment for $24 \mathrm{~h}$ suppressed the growth of Huh-7 cells, and this inhibitory effect was enhanced by increasing concentrations of cecropinXJ. CecropinXJ at a concentration of $50 \mu \mathrm{mol} / 1$ significantly inhibited the proliferation of Huh-7 cells, with an inhibitory rate of $\leq 53 \%(\mathrm{P}<0.05)$. Furthermore, the inhibition effects of $50 \mu \mathrm{mol} / 1$ cecropinXJ on Huh-7 cells was similar to those caused by $10 \mu \mathrm{mol} / 1$ cisplatin (Fig. 1).

Detection of tumor cell apoptosis rate by flow cytometry. Since cell viability was significantly inhibited by cecropinXJ, it was critical to determine which type of cell death was induced by this AMP in Huh-7 cells $(\mathrm{P}<0.05)$. For that purpose, an Annexin V/PI assay. Flow cytometry assay with Annexin V/PI double staining revealed that cecropinXJ induced Huh-7 cell apoptosis. The apoptosis rate increased, whereas the number of necrotic cells did not significantly increase with cecropinXJ concentration or time. CecropinXJ treatment (5-50 $\mu \mathrm{mol} / \mathrm{l})$ for $24 \mathrm{~h}$ increased Huh7 cell apoptosis at both early and late stages, in a dose-dependent manner. The percentage of total apoptotic cells significantly increased from $3.76 \pm 0.53 \%$ (untreated) to

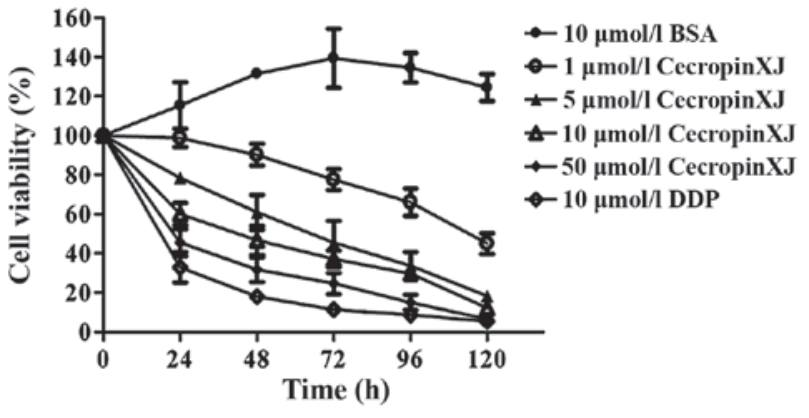

Figure 1. Effects of different concentrations of cecropinXJ and incubation times on the viability of treated Huh-7 cells. The results are expressed as the mean \pm standard deviation of three independent experiments. BSA, bovine serum albumin; DDP, cisplatin.

$15.24 \pm 0.31 \%$ at $5 \mu \mathrm{mol} / 1$ cecropinXJ, $23.13 \pm 0.26 \%$ at $10 \mu \mathrm{mol} / 1$ cecropinXJ and $44.77 \pm 0.42 \%$ at $50 \mu \mathrm{mol} / 1$ cecropinXJ (Fig. 2). Furthermore, the number of apoptotic cells increased with $10 \mu \mathrm{mol} / \mathrm{l}$ cecropinXJ treatment for $12 \mathrm{~h}$, and was significantly elevated at $24 \mathrm{~h}(\mathrm{P}<0.05)$ (Fig. 2). This result indicated that cecropinXJ induced apoptotic cell death in Huh-7 cells.

Cell cycle analysis of cecropinXJ on Huh-7 cells by flow cytometry. Flow cytometry was used to determine the effects of cecropinXJ on cell cycle distribution (Fig. 3). Upon treatment with cecropinXJ for $24 \mathrm{~h}$, the percentage of S-phase cells was significantly higher in the treated group than in the control group $(\mathrm{P}<0.05)$. These results suggested that cecropin $\mathrm{XJ}$ arrested the cell cycle at the $\mathrm{S}$ phase in vitro.

CecropinXJ caused the loss of the $\Delta \psi_{m}$ and the release of cyt $\mathrm{c}$ in Huh-7 cells. Since the loss of the $\Delta \psi_{\mathrm{m}}$ acts as a key regulator in the intrinsic apoptosis pathway (24), it was next examined whether the $\Delta \psi_{\mathrm{m}}$ was affected by cecropinXJ (Fig. 4). The mean fluorescence intensity of cells treated with 5,10 and $50 \mu \mathrm{mol} / 1$ cecropinXJ for $24 \mathrm{~h}$ decreased to $658.17 \pm 44.57,350.07 \pm 52.23$ and $147.27 \pm 23.99$, respectively, compared with the untreated control (1,196 \pm 76.12$)$ (Fig. 4B). CecropinXJ also induced the release of cyt $c$ into the cytosol (Fig. 4C) and triggered the intrinsic apoptosis pathway. This suggests that cecropinXJ may initiate apoptosis through depolarization of the $\Delta \psi_{\mathrm{m}}$.

CecropinXJ induced caspase-dependent apoptosis and regulated the expression of Bcl-2-family proteins in Huh-7 cells. To further investigate whether cecropinXJ induced apoptosis in Huh-7 cells through the caspase-dependent pathway, the present study investigated whether caspase-3 and PARP were cleaved in cecropinXJ-treated cells. According to the results of western blot analysis, the above enzymes were cleaved in a dose-dependent manner (Fig. 5), indicating that cecropinXJ induced caspase-dependent apoptosis in the Huh-7 HCC cell line. Bcl-2-family members are important in the mitochondrial pathway of apoptosis, and are divided into pro- and anti-apoptotic family members, according to whether they promote or inhibit apoptosis (25). As indicated in Fig. 5, the pro-apoptotic proteins Bad and Bax were upregulated, whereas the anti-apoptotic protein $\mathrm{Bcl}-2$ was downregulated, following treatment with cecropinXJ. 
A

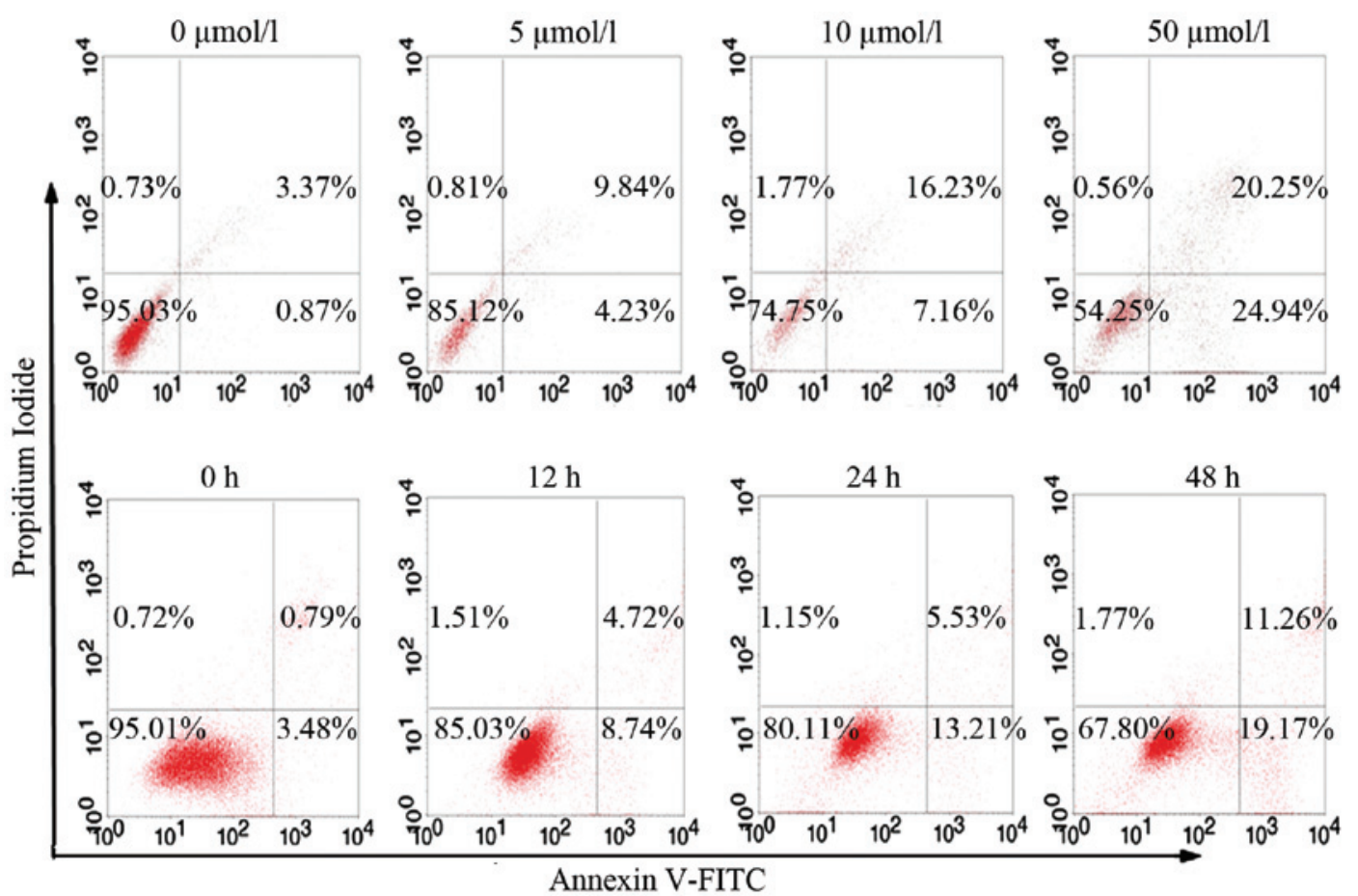

Figure 2. CecropinXJ induced apoptosis in Huh-7 cells. Huh-7 cells were treated with (A) different concentrations of cecropinXJ $(0,5,10$ and $50 \mu$ mol/l) for $24 \mathrm{~h}$, or with (B) $10 \mu \mathrm{mol} / 1$ cecropinXJ for 0,12, 24 and $48 \mathrm{~h}$. Cells were stained with Annexin V-fluorescein isothiocyanate and propidium iodide, and analyzed by fluorescence-activated cell sorting. The number of apoptotic cells (Annexin $\mathrm{V}^{+}$) was indicated as the percentage of gated cells. (B) The percentage of apoptotic cells was expressed as the mean \pm standard deviation of triplicate samples. FITC fluorescein isothiocyanate, PI, propidium iodide.
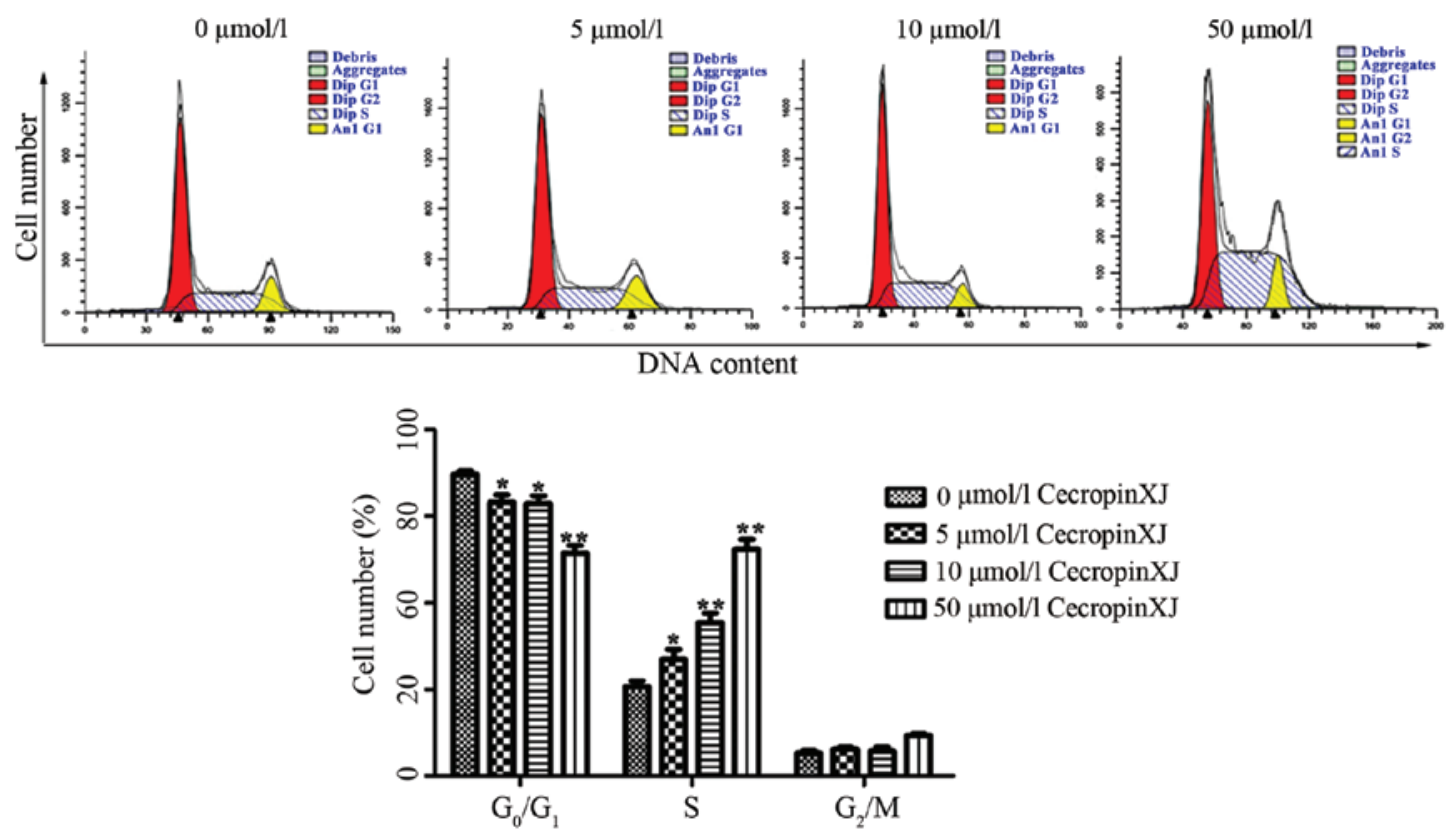

Figure 3. CecropinXJ arrested the cell cycle of Huh-7 cells at the S phase. Huh-7 cells were treated with different concentrations of cecropinXJ $(0,5,10$ and $50 \mu \mathrm{mol} / \mathrm{l}$ ) for $24 \mathrm{~h}$. (A) Subsequently, cells were stained with DNA staining solution, and analyzed by fluorescence-activated cell sorting. (B) The percentage of cells in the $\mathrm{G}_{0} / \mathrm{G}_{1}, \mathrm{~S}$ and $\mathrm{G}_{2} / \mathrm{M}$ phases of the cell cycle was expressed as the mean \pm standard deviation of triplicate samples. ${ }^{*} \mathrm{P}<0.05$ and ${ }^{* *} \mathrm{P}<0.01$. Dip, diploid; Anl, aneupl.

\section{Discussion}

AMPs are a kind of small peptides that specifically interact with membranes and affect the proliferation and apoptosis of various tumor cells $(26,27)$. AMPs have gained great attention due to their antitumor effects (28). Since Moore et al (29) first discovered the antitumor activity of cecropin B against mammalian cancer cells, other studies have reported the cyototoxicity of cecropin-family members on gastric, bladder, liver and other types of cancer cells, but without 
A

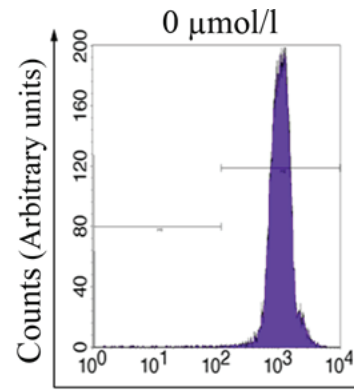

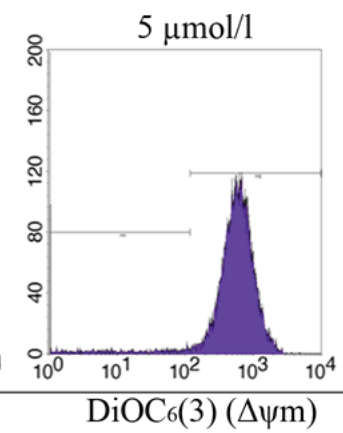
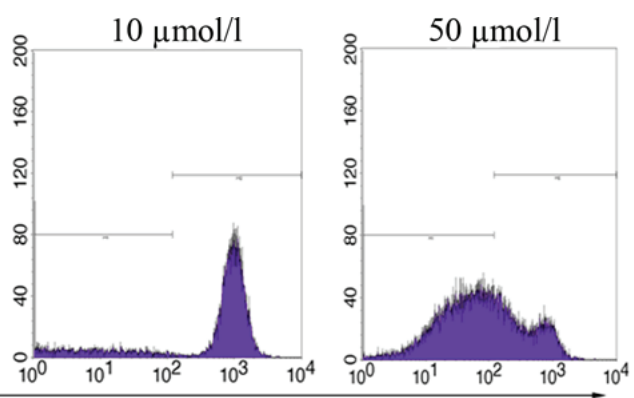

B

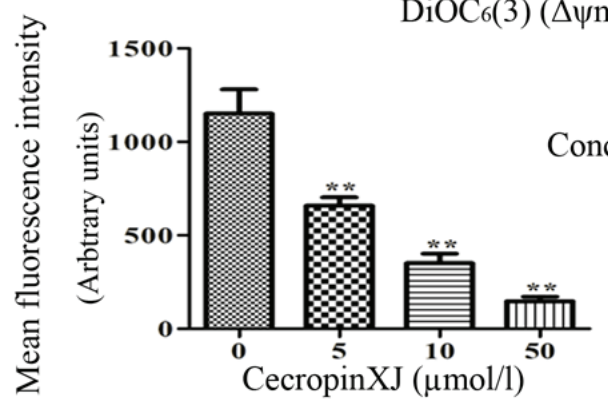

C

CecropinXJ (24 h)

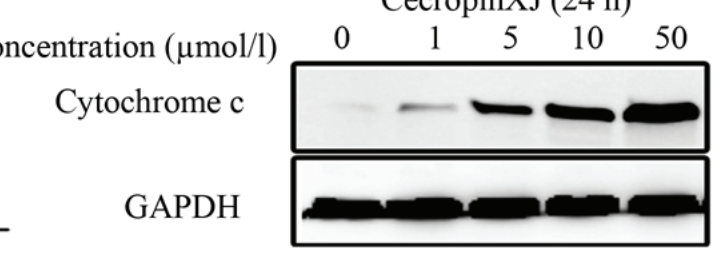

Figure 4. CecropinXJ caused the loss of the $\Delta \psi_{\mathrm{m}}$ and the release of cyt $c$. Huh-7 cells treated with 5,10 and $50 \mu \mathrm{mol} / 1 \mathrm{cecropinXJ}$ for $24 \mathrm{~h}$ were trypsinized to evaluate the $\Delta \psi_{\mathrm{m}}$ by 3,3'-dihexyloxacarbocyanine iodide staining. (A) The counts represent the percentages of cells with depolarized mitochondria. The results of a representative experiment are shown. (B) Data are presented as the mean \pm standard deviation of the percentage of cells that retained polarized mitochondria from three different experiments. Statistical analyses indicated a significant $\left({ }^{* *} \mathrm{P}<0.01 \mathrm{vs} .0 \mu \mathrm{mol} / 1 \mathrm{cecropinXJ}\right)$ decrease in the number of cells with depolarized membrane following cecropinXJ treatment (C) Western blot analysis of cyt $c$ release following treatment of cells with $0,1,5,10$ and $50 \mu$ mol/1 cecropinXJ for $24 \mathrm{~h}$. GAPDH, glyceraldehyde 3-phosphate dehydrogenase; $\Delta \psi_{\mathrm{m}}$, mitochondrial membrane potential; cyt $c$, cytochrome $c$.

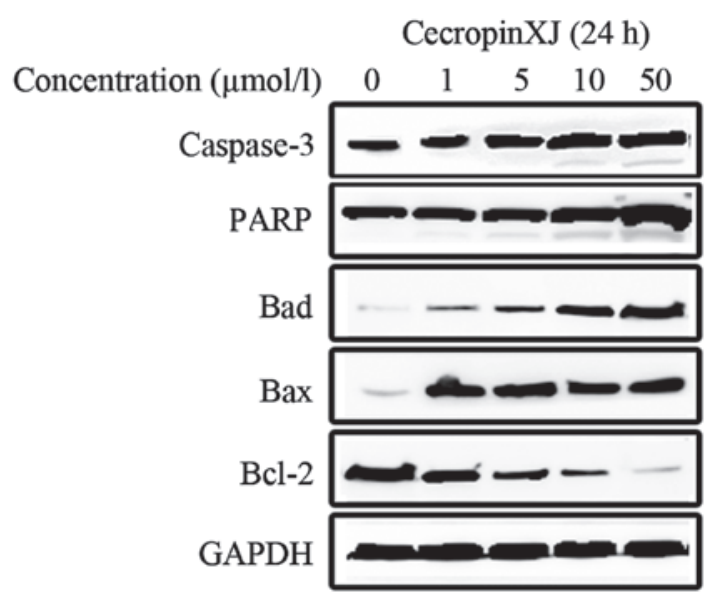

Figure 5. Western blot analysis of the activation of apoptosis-related enzymes and expression of proteins of the Bcl-2 family. Huh-7 cells were treated with $0,1,5,10$ and $50 \mu \mathrm{mol} / 1$ cecropinXJ for $24 \mathrm{~h}$, and their cellular extracts were analyzed by western blotting for detection of the cleaved forms of caspase-3 and poly(ADP-ribose) polymerase, and the expression levels of $\mathrm{Bcl}-2$, Bcl-2-associated death promoter and $\mathrm{Bcl}-2$-associated $\mathrm{X}$ protein, in order to evaluate whether cecropinXJ induced cell apoptosis through the caspase-dependent pathway. Glyceraldehyde 3-phosphate dehydrogenase was used as an internal control. GAPDH, glyceraldehyde 3-phosphate dehydrogenase; PARP, poly(ADP-ribose) polymerase; Bcl-2, B-cell lymphoma 2; $\mathrm{Bad}, \mathrm{Bcl}-2$-associated death promoter; Bax, Bcl-2-associated X protein.

causing damage to human normal cells (30). Thus, cecropins may be good candidates for the development of antitumor agents. In recent years, a number of studies have reported that AMPs could inhibit the growth of HCC, including Musca domestica cecropin (12), melittin (31) and PR-39 (32). In the present study, cecropinXJ inhibited the proliferation of Huh-7 cells, and the inhibitory rate of $50 \mu \mathrm{mol} / 1$ cecropin on HCC was $36.6 \pm 0.1 \%$, which was higher than that of $M$. domestica cecropin (12).

Previous studies have demonstrated that antitumor drugs generally inhibit tumor proliferation through the induction of apoptosis in sensitive tumor cells, and their antitumor effects are associated with the drug-induced activation of apoptosis in the tumor cells. Therefore, the induction of apoptosis to treat tumors has become a novel target for the development of antitumor drugs, and constitutes a novel direction in tumor pharmacology research. In the present study, flow cytometry revealed that cecropinXJ induced apoptosis in Huh-7 HCC cells.

The mechanism of cecropins-induced apoptosis in vitro has been previously reported (11). Cecropin A, a 37-residue linear AMP produced by the cecropia moth, is able to induce apoptosis in HL-60 cells through a signaling mechanism that is mediated by the mitochondria but is independent of caspase activation (19). In the present study, the $\Delta \psi_{\mathrm{m}}$ decreased following cecropin XJ treatment, which also resulted in the release of cyt $c$ into the cytoplasm of Huh-7 cells, suggesting that cecropin XJ-mediated apoptosis may be associated with mitochondrial dysfunction. To further understand the mechanism of cell apoptosis mediated by cecropinXJ, its effects on the expression of caspase-family and Bcl-2-family proteins were examined. The results indicated that caspase- 3 and PARP were cleaved, while Bad and Bax were upregulated and Bcl-2 was downregulated in a time-dependent manner, indicating that cecropinXJ induced caspase-dependent apoptosis in the Huh-7 HCC cell line. These findings suggested the existence of a common pathway that involves the activation of the family of proteolytic enzymes known as caspases (33). One of the pathways that lead to caspase activation is triggered by cyt $c$, following its release from the mitochondria into the cytoplasm, which is 
called the 'intrinsic' pathway of apoptosis (34). Bcl-2 blocks the release of cyt $c$ from the mitochondria (35), suggesting that the mitochondria are the principal sites for apoptotic regulation by the Bcl-2 family.

In conclusion, the present study has demonstrated that cecropinXJ possesses antitumor activity against human $\mathrm{HCC}$ Huh-7 cells in vitro. The mechanism of cecropinXJ-induced apoptosis involves the loss of the $\Delta \psi_{\mathrm{m}}$, the release of cyt $c$ from the mitochondria and the activation of caspase- 3 and PARP, which suggests that cecropinXJ induced cell apoptosis possibly via the mitochondrial pathway. Therefore cecropinXJ may be a potential candidate for the treatment of HCC.

\section{Acknowledgements}

The present study was supported by grants from the National Natural Science Foundation of China (no. 31500752), the Doctoral Start-up Fund of Xinjiang University (no. BS150241) and the High-Tech Research and Development Program of Xinjiang (no. 201110101).

\section{References}

1. Somboon K, Siramolpiwat S and Vilaichone RK: Epidemiology and survival of hepatocellular carcinoma in the central region of Thailand. Asian Pac J Cancer Prev 15: 3567-3570, 2014.

2. Chen W, Zheng R, Zhang S, Zhao P, Li G, Wu L and He J: The incidences and mortalities of major cancers in China, 2009. Chin J Cancer 32: 106-112, 2013.

3. Llovet JM, Burroughs A and Bruix J: Hepatocellular carcinoma. Lancet 362: 1907-1917, 2003.

4. Zolfagharzadeh F and Roshan VD: Pretreatment hepatoprotective effect of regular aerobic training against hepatic toxicity induced by doxorubicin in rats. Asian Pac J Cancer Prev 14: 2931-2936, 2013

5. Sostelly A, Henin E, Chauvenet L, Hardy-Bessard AC, Jestin-Le Tallec V, Kirsher S, Leyronnas C, Ligeza-Poisson C, Ramdane S, Salavt J, et al: Can we predict chemo-induced hematotoxicity in elderly patients treated with pegylated liposomal doxorubicin? Results of a population-based model derived from the DOGMES phase II trial of the GINECO. J Geriatr Oncol 4 48-57, 2013.

6. Cruciani RA, Barker JL, Zasloff M, Chen HC and Colamonici O: Antibiotic magainins exert cytolytic activity against transformed cell lines through channel formation. Proc Natl Acad Sci USA 88: 3792-3796, 1991.

7. Jin XB, Li XB, Zhu JY, Lu XM, Shen J, Chu FJ and Mei HF: The target of Musca domestica cecropin on human hepatocellular carcinoma BEL-7402 cells. Zhongguo Ji Sheng Chong Xue Yu Ji Sheng Chong Bing Za Zhi 29: 271-273, 2011 (In Chinese).

8. Jin XB, Wang YJ, Liang LL, Pu QH, Shen J, Lu XM, Chu FJ and Zhu JY: Cecropin suppresses human hepatocellular carcinoma BEL-7402 cell growth and survival in vivo without side-toxicity. Asian Pac J Cancer Prev 15: 5433-5436, 2014.

9. Boman HG, Nilsson-Faye I, Paul K and Rasmuson T Jr: Insect immunity. I. Characteristics of an inducible cell-free antibacterial reaction in hemolymph of Samia cynthia pupae. Infect Immun 10: 136-145, 1974

10. Steiner H, Hultmark D, Engström A, Bennich H and Boman HG: Sequence and specificity of two antibacterial proteins involved in insect immunity. Nature 292: 246-248, 1981.

11. Suttmann H, Retz M, Paulsen F, Harder J, Zwergel U, Kamradt J, Wullich B, Unteregger G, Stöckle $M$ and Lehmann J: Antimicrobial peptides of the Cecropin-family show potent antitumor activity against bladder cancer cells. BMC Urol 8: 5, 2008.

12. Jin X, Mei H, Li X, Ma Y, Zeng AH, Wang Y, Lu X, Chu F, Wu Q and Zhu J: Apoptosis-inducing activity of the antimicrobial peptide cecropin of Musca domestica in human hepatocellular carcinoma cell line BEL-7402 and the possible mechanism. Acta Biochim Biophys Sin (Shanghai) 42: 259-265, 2010.
13. Pan WR, Chen PW, Chen YL, Hsu HC, Lin CC and Chen WJ: Bovine lactoferricin $\mathrm{B}$ induces apoptosis of human gastric cancer cell line AGS by inhibition of autophagy at a late stage. J Dairy Sci 96: 7511-7520, 2013

14. Lin WJ, Chien YL, Pan CY, Lin TL, Chen JY, Chiu SJ and Hui CF: Epinecidin-1, an antimicrobial peptide from fish (Epinephelus coioides) which has an antitumor effect like lytic peptides in human fibrosarcoma cells. Peptides 30: 283-290, 2009.

15. Hui L, Leung K and Chen HM: The combined effects of antibacterial peptide cecropin A and anti-cancer agents on leukemia cells. Anticancer Res 22: 2811-2816, 2002.

16. Yeaman MR and Yount NY: Mechanisms of antimicrobial peptide action and resistance. Pharmacol Rev 55: 27-55, 2003.

17. Chou HT, Wen HW, Kuo TY, Lin CC and Chen WJ: Interaction of cationic antimicrobial peptides with phospholipid vesicles and their antibacterial activity. Peptides 31: 1811-1820, 2010.

18. Chen HM, Wang W, Smith D and Chan SC: Effects of the anti-bacterial peptide cecropin B and its analogs, cecropins $\mathrm{B} 1$ and B2, on liposomes, bacteria, and cancer cells. Biochim Biophys Acta 1336: 171-179, 1997.

19. Cerón JM, Contreras-Moreno J, Puertollano E, de Cienfuegos GÁ, Puertollano MA and de Pablo MA: The antimicrobial peptide cecropin A induces caspase-independent cell death in human promyelocytic leukemia cells. Peptides 31: 1494-1503, 2010.

20. Li JY, Zhang FC and Ma ZH: Prokaryotic expression of cecropin gene isolated from the silkworm Bombyx mori Xinjiang race and antibacterial activity of fusion cecropin. Acta Entomologica Sinica 47: 407-411, 2004 (In Chinese).

21. Xia L, Liu Z, Ma J, Sun S, Yang J and Zhang F: Expression, purification and characterization of cecropin antibacterial peptide from Bombyx mori in Saccharomyces cerevisiae. Protein Expr Purif 90: 47-54, 2013.

22. Xia L, Zhang F, Liu Z, Ma J and Yang J: Expression and characterization of cecropinXJ, a bioactive antimicrobial peptide from Bombyx mori (Bombycidae, Lepidoptera) in Escherichia coli. Exp Ther Med 5: 1745-1751, 2013.

23. Xia L, Wu Y, Kang S, Ma J, Yang J and Zhang F: CecropinXJ, a silkworm antimicrobial peptide, induces cytoskeleton disruption in esophageal carcinoma cells. Acta Biochim Biophys Sin (Shanghai) 46: 867-876, 2014.

24. Cerón JM,Contreras-Moreno J,Puertollano E, de Cienfuegos GÁ, Puertollano MA and de Pablo MA: The antimicrobial peptide cecropin A induces caspase-independent cell death in human promyelocytic leukemia cells. Peptides 31: 1494-1503, 2010.

25. Kuwana T and Newmeyer DD: Bcl-2-family proteins and the role of mitochondria in apoptosis. Curr Opin Cell Biol 15: 691-699, 2003.

26. Chen YL, Li JH, Yu CY, Lin CJ, Chiu PH, Chen PW, Lin CC and Chen WJ: Novel cationic antimicrobial peptide GW-H1 induced caspase-dependent apoptosis of hepatocellular carcinoma cell lines. Peptides 36: 257-265, 2012.

27. Huh JE, Kang JW, Nam D, Baek YH, Choi DY, Park DS and Lee JD: Melittin suppresses VEGF-A-induced tumor growth by blocking VEGFR-2 and the COX-2-mediated MAPK signaling pathway. J Nat Prod 75: 1922-1929, 2012.

28. Papo N and Shai Y: Host defense peptides as new weapons in cancer treatment. Cell Mol Life Sci 62: 784-790, 2005.

29. Moore AJ, Devine DA and Bibby MC: Preliminary experimental anticancer activity of cecropins. Pept Res 7: 265-269, 1994.

30. Chernysh S, Kim SI, Bekker G, Pleskach VA, Filatova NA, Anikin VB, Platonov VG and Bulet P: Antiviral and antitumor peptides from insects. Proc Natl Acad Sci USA 99: 12628-12632, 2002.

31. Li B, Gu W, Zhang C, Huang XQ, Han KQ and Ling CQ: Growth arrest and apoptosis of the human hepatocellular carcinoma cell line BEL-7402 induced by melittin. Onkologie 29: 367-371, 2006.

32. Ohtake T, Fujimoto Y, Ikuta K, Saito H, Ohhira M, Ono M and Kohgo Y: Proline-rich antimicrobial peptide, PR-39 gene transduction altered invasive activity and actin structure in human hepatocellular carcinoma cells. Br J Cancer 81: 393-403, 1999.

33. Thornberry NA and Lazebnik Y: Caspases: Enemies within. Science 281: 1312-1316, 1998.

34. Liu X, Kim CN, Yang J, Jemmerson R and Wang X: Induction of apoptotic program in cell-free extracts: Requirement for dATP and cytochrome $c$. Cell 86: 147-157, 1996.

35. Yang J, Liu X, Bhalla K, Kim CN, Ibrado AM, Cai J, Peng TI, Jones DP and Wang X: Prevention of apoptosis by Bcl-2: Release of cytochrome $c$ from mitochondria blocked. Science 275: 1129-1132, 1997. 